\title{
RETHINKING EXCESSIVE FORCE
}

\section{R. WILSON FREYERMUTH*}

Each year claimants file thousands of section 1983 actions against law enforcement or prison officials. Many of these claimants allege that officials used excessive force against them in violation of their constitutional rights. Despite the large number of excessive force cases in the federal courts, however, the Supreme Court has decided only two excessive force cases brought under section 1983. In Whitley v. Albers, ${ }^{1}$ the Court elaborated the appropriate standard for determining whether the shooting of a prisoner violated the eighth amendment. In Tennessee $v$. Garner, ${ }^{2}$ the Court applied the fourth amendment to strike down a Tennessee statute that authorized the use of deadly force to apprehend a nondangerous fleeing suspect. In each case, the Court recognized that the application of force implicated a specific fourth or eighth amendment right and applied the standard developed to protect that right.

Against this background, let us pose a hypothetical. Suppose that the police see a man and his companion exit a grocery store. Because the man is in a highly agitated state, the police stop the two to investigate. The companion informs the police that the man is an epileptic and is suffering a mild seizure. A brief investigation by one officer reveals that the man has committed no crime and possesses no weapon. Another officer, however, mistakes the man's erratic beliavior for a reaction to hallucinogenic drugs. This officer proceeds to push the man to the ground, handcuff him, and throw him agamst the police car. Upon checking the man's wallet, the officer discovers a medical identification card that confirms the man's epilepsy. The officer then shoves the man into the backseat of the police car and drives him home, ignoring his pleas for medical assistance. Durmg the incident, the man suffers several broken bones and moderately severe head injuries. He then files a section 1983 action claiming that the officer used excessive force.

If this man's attorneys read only Suprenie Court decisions, they would advise him that Garner requires a court to apply the fourth

* B.S., B.A. 1984, University of North Carolina at Chapel Hill; J.D. 1987, Duke University School of Law. The author wishes to thank Roger Brooks for his helpful suggestions. The author also wishes to extend special thanks to Alan Wingfield for his helpful criticism on earlier drafts of this comment.

1. 475 U.S. 312 (1986).

2. 471 U.S. 1 (1985). 
amendment to determine whether the police used excessive force against him. This fourth amendment inquiry would be a wholly objective onewhether the "totality of the circuinstances" justified the officer's actions. ${ }^{3}$ If his attorneys read the decisions of most federal courts of appeals, however, they would discover that their prior advice would be erroneous in those courts. The lower federal courts have developed and apphed a different standard in all section 1983 excessive force cases. Under this standard, first developed in Johnson v. Glick, ${ }^{4}$ the decisionmaker must consider-among other factors-whether the official apphed force "in a good faith effort to mamtain or restore discipline or mahiciously and sadistically for the very purpose of causing harm."s

This standard, with its roots deep in the heart of substantive due process, has until recently enjoyed unanimous if unreflective approval in the federal district and circuit courts. These courts have applied this standard mechamically - to the claims of prisoners, pretrial detainees, suspects and free citizens alike-regardless of the surrounding circumstances or the specific constitutional right imphicated by the use of force. ${ }^{6}$ The natural effect of this practice has been to create an abstract constitutional right to be free of excessive force, defined and protected solely by the standard set forth in Johnson. ${ }^{7}$

As this conment demonstrates, this generic substantive due process standard requires the decisionmaker to consider issues - such as an officer's subjective motivation or the extent of the plaintiff's injury-that are often irrelevant under the standards developed by the Supreme Court to protect the fourth or eighth amendment right implicated by the use of force. The United States Court of Appeals for the Seventh Circuit recognized this inconsistency in Lester v. City of Chicago ${ }^{8}$ and rejected substantive due process analysis of claims alleging excessive force in arrest. The rest of the circuits should follow Lester of their own vohtion, or the Supreme Court should leave them no choice. Furthermore, courts should make clear that substantive due process need not play any role in deciding excessive force cases and that for most citizens the fourth amendment provides the primary source of constitutional protection from excessive force. ${ }^{9}$

3. Id. at $8-9$.

4. 481 F.2d 1028, 1032-33 (2d Cir.), cert. denied, 414 U.S. 1033 (1973).

5. Id. at 1033 .

6. See infra notes 10-25 and accompanying text.

7. See infra notes 99-104 and accompanying text.

8. 830 F.2d 706, 713 (7th Cir. 1987).

9. See infra notes $36-98$ and accompanying text. 
The circuits' excessive force standard originated in the 1973 Second Circuit decision in Johnson v. Glick ${ }^{10}$ Johnson involved a pretrial detainee who had filed a section 1983 action claiming that a prison guard assaulted him. In evaluating the detainee's claim, the court did not apply the fourth or eighth amendinent. ${ }^{11}$ Instead, the court held that one's constitutional protection froin excessive force "is not limited to conduct violating the specific command of the Eighth Amendment, or ... of the Fourth. ... [Q]uite apart from any 'specific' of the Bill of Rights, application of undue force by law enforcement officers deprives a suspect of liberty without due process of law." 12 In support of its substantive due process standard, the Johison court cited Rochin v. California, ${ }^{13}$ in which the Supreme Court used the due process clause to reverse a conviction based on evidence obtained by punping the defendant's stomach.

Analogizing from Rochin, the Johnson court held that an officer's use of force is constitutionally excessive if the force "shocks the conscience." 14 The Johnson court, having imposed upon itself a rather inexact standard, set forth four factors for courts to apply in determining whether the use of force shocks the conscience:

the need for the application of force, the relationship between the need and the amount of force that was used, the extent of injury inflicted, and whether the force was applied in a good faith effort to maintain or restore discipline or maliciously and sadistically for the very purpose of causing harm. ${ }^{15}$

These factors, or similar formulations thereof, gained rapid acceptance in the federal courts of appeals. ${ }^{16}$ Roughly half of the appellate

10. 481 F.2d 1028 (2d Cir.), cert, denied, 414 U.S. 1033 (1973).

11. The Johnson court gave two reasons for refusing to apply the eighth amendment. First, the court believed that a spontaneous attack by a prison guard was not "punishment." Id. at 1032. But cf. Whitley v. Albers, 475 U.S. 312 (1986) (excessive force claim by prisoner analyzed under eighth amendment). Second, the court correctly believed that the eighth amendment's protections did not apply until after conviction and sentence. Johnson, 481 F.2d at 1032. See Ingraham v. Wright, 430 U.S. $651,671 \mathrm{n} .40$ (1977) ("[T] he state does not acquire the power to punish with which the Eighth Amendment is concerned until after it has secured formal adjudication of guilt in accordance with due process of law.").

The Johnson court apparently decided not to apply the fourth amendment based on the weight of prior authority. Johnson, 481 F.2d at 1033. See infra notes $52-54$ and accompanying text.

12. 481 F.2d at 1032.

13. 342 U.S. 165 (1952). See Johnson, 481 F.2d at 1032-33 (citing and discussing Rochin).

14. 481 F.2d at 1033 (citing Rochin, 342 U.S. at 172).

15. Id.

16. Some circuits have applied a three-factor standard that is essentially identical to the Johnson standard. Under this standard, a state officer's use of force is unconstitutional if it "1) caused severe injuries, 2) was grossly disproportionate to the need for action under the circumstances, and 3) was inspired by malice rather than merely careless or unwise excess of zeal so that it amounted to an abuse of official power that shocks the conscience." Gumz v. Morrissette, 772 F.2d 1395, 1400 
decisions applying the Johnson factors involve the excessive force claims of convicted prisoners. Some courts have analyzed these claims under the eighth amendment, ${ }^{17}$ others under the due process clause, ${ }^{18}$ and others without identifying any specific constitutional provision. ${ }^{19}$ The remainder of the decisions involve excessive force claims brought either by "bystanders" or by persons subjected to an arrest or investigatory stop. Some courts have evaluated these claims under the due process clause, ${ }^{20}$ others under both the fourth amendinent and the due process clause, ${ }^{21}$ and yet others without identifying a specific constitutional provision. ${ }^{22} \mathrm{~A}$ few decisions involve the excessive force claims of pretrial detainees. The

(7th Cir. 1985), cert. denied, 475 U.S. 1123 (1986), overruled, Lester v. City of Chicago, 830 F.2d 706 (7th Cir. 1987). See also Wise v. Bravo, 666 F.2d 1328, 1333-34 (10th Cir. 1981); Shillingford v. Holmes, 634 F.2d 263, 265 (5th Cir. Unit A 1981).

17. See, e.g., Davis v. Lane, 814 F.2d 397, 400 (7th Cir. 1987); Brown v. Smith, 813 F.2d 1187, 1188-90 (11th Cir. 1987); McRorie v. Shimoda, 795 F.2d 780, 784 (9th Cir. 1986) (concurrently analyzed under due process clause); El'Amin v. Pearce, 750 F.2d 829, 831-33 (10th Cir. 1984); Bates v. Jean, 745 F.2d 1146, 1151-52 (7th Cir. 1984) (concurrently analyzed under fifth amendment due process clause); Soto v. Dickey, 744 F.2d 1260, 1268-71 (7th Cir. 1984), cert. denied, 470 U.S. 1085 (1985); Bailey v. Turner, 736 F.2d 963, 969-72 (4th Cir. 1984); Wilhams v. Mussomelli, 722 F.2d 1130, 1132-34 (3d Cir. 1983) (suggesting that same standard may apply under due process clause); McFadden v. Lucas, 713 F.2d 143, 146-47 (5th Cir.), cert. denied, 464 U.S. 998 (1983); Sampley v. Ruettgers, 704 F.2d 491, 494-96 (10th Cir. 1983); Stringer v. Rowe, 616 F.2d 993, 998-1000 (7th Cir. 1980).

18. McRorie v. Shimoda, 795 F.2d 780, 784-86 (9th Cir. 1986) (concurrently analyzed under eighth amendment); Franklin v. Aycock, 795 F.2d 1253, 1258-59 (6th Cir. 1986); Burton v. Livingston, 791 F.2d 97, 99-101 (8th Cir. 1986); Bates v. Jean, 745 F.2d 1146, 1151-52 (7th Cir. 1984) (concurrently analyzed under eighth amendment); Freeman v. Franzen, 695 F.2d 485, 491-92 (7th Cir. 1982), cert. denied, 463 U.S. 1214 (1983); Martinez v. Rosado, 614 F.2d 829, 831-32 (2d Cir. 1980); Meredith v. Arizona, 523 F.2d 481, 482-84 (9th Cir. 1975).

19. Massop v. Coughlin, 770 F.2d 299, 301 (2d Cir. 1985); Hodges v. Stanley, 712 F.2d 34, 36 (2d Cir. 1983); King v. Blankenship, 636 F.2d 70, 72-73 (4th Cir. 1980); Furtado v. Bishop, 604 F.2d 80, $95-96$ (1st Cir. 1979), cert. denied, 444 U.S. 1035 (1980).

20. Dale v. Janklow, 828 F.2d 481, 484-85 (8th Cir. 1987) (urrest); Robison v. Via, 821 F.2d 913, 923-25 (2d Cir. 1987) (no arrest); Brower v. County of Inyo, 817 F.2d 540, 543-44 (9th Cir. 1987) (apprehension at roadblock), petition for cert. filed, 56 U.S.L.W. 3251 (U.S. Aug. 13, 1987) (No. 87-248); Byrd v. Clark, 783 F.2d 1002, 1005-07 (11th Cir. 1986) (arrest); Rutherford v. City of Berkeley, 780 F.2d 1444, 1446-48 (9th Cir. 1986) (arrest); Fundiller v. City of Cooper City, 777 F.2d 1436, 1439-42 (11th Cir. 1985) (arrest); Wilson v. Beebe, 770 F.2d 578, $581-83$ (6th Cir. 1985) (en banc) (arrest); Wise v. Bravo, 666 F.2d 1328, 1333-35 (10th Cir. 1981) (no arrest); Shillingford v. Holmes, 634 F.2d 263, 265 (5th Cir. Unit A 1981) (bystander).

21. Smith v. City of Fontana, 818 F.2d 1411, 1416-17 (9th Cir.) (stop), cert. denied, $108 \mathrm{~S}$. Ct. 311 (1987); Fernandez v. Leonard, 784 F.2d 1209, 1213-17 (1st Cir. 1986) (apprehension by deadly force); Gilmere v. City of Atlanta, 774 F.2d 1495, 1499-1502 (11th Cir. 1985) (en banc) (questioning before arrest), cert. denied, 476 U.S. 1115 and 476 U.S. 1124 (1986).

22. Graham v. City of Charlotte, 827 F.2d 945, 948 (4th Cir. 1987) (stop); Popham v. City of Kennesaw, 820 F.2d 1570, 1576-77 (11th Cir. 1987) (arrest); Coon v. Ledbetter, 780 F.2d 1158, 1162-64 (5th Cir. 1986) (arrest); Patzner v. Burkett, 779 F.2d 1363, 1371 (8th Cir. 1985) (arrest); Bauer v. Norris, 713 F.2d 408, 411-13 (8th Cir. 1983) (arrest). 
circuits have analyzed these claims under the due process clause. ${ }^{23}$

In all of these types of cases-regardless of the plaintiff's status or the circumstances surrounding the use of force-the circuits have applied the Johnson factors in the same manner. Despite having recent opportunities to do so, however, the Supreme Court has never adopted such an absolute approach. In fact, careful analysis of the Supreme Court's decisions in Whitley ${ }^{24}$ and Garner ${ }^{25}$ compels the conclusion that the continued application of the Johnson standard in all excessive force cases is incorrect.

\section{II}

Unlike the circuits, the Supreme Court has not mandated a subjective substantive due process approach for evaluating all excessive force claims by prisoners. In Whitley v. Albers, ${ }^{26}$ the Court addressed the limitations that the eighth amendinent places on an official's use of force against a prisoner. Whitley involved a prisoner who was shot by prison officials who were attempting to free hostages taken during a prison riot. The prisoner subsequently filed a section 1983 action claiming that the shooting violated the eighth amendment.

In a five-to-four opinion, the Court rejected the prisoner's claim. The Court reiterated that the central requirement of an eighth amendment violation is the " 'unnecessary and wanton infliction of pain" " and that this standard remains the same in all eighth amendment cases. ${ }^{27}$ The Court recognized, however, that courts must apply this standard "with due regard for differences in the kind of conduct against which an Eighth Amendment objection is lodged." 28 In other words, courts should extend different levels of deference toward prison officials facing different circumstances. In many cases a state's responsibility to attend to the needs or honor the rights of prisoners does not "clash with other equally important governmental responsibilities." 29 In such cases, the existence of an eighth amendment violation can be determined "without

23. Justice v. Dennis, 834 F.2d 380, 383 n.4 (4th Cir. 1987) (en banc); Maddox v. City of Los Angeles, 792 F.2d 1408, 1413-16 (9th Cir. 1986); H.C. ex rel. by Hewett v. Jarrard, 786 F.2d 1080, 1084-86 (11th Cir. 1986); Owens v. City of Atlanta, 780 F.2d 1564, 1566-67 (11th Cir. 1986); Norris v. District of Columbia, 737 F.2d 1148, 1150-52 (D.C. Cir. 1984); Smith v. Iron County, 692 F.2d 685, 686-88 (10th Cir. 1982); Lock v. Jenkins, 641 F.2d 488, 495-96 (7th Cir. 1981); Putman v. Gerloff, 639 F.2d 415, 420-22 (8th Cir. 1981); Arroyo v. Schaefer, 548 F.2d 47, 49-50 (2d Cir. 1977); Hamilton v. Chaffin, 506 F.2d 904, 909-10 (Sth Cir. 1975).

24. See infra notes $26-32$ and accompanying text.

25. See infra notes $41-53$ and accompanying text.

26. 475 U.S. 312 (1986).

27. Id. at 319 (quoting Ingraharn v. Wright, 430 U.S. 651,670 (1977)).

28. Id. at 320 .

29. Id. 
the necessity of balancing competing institutional concerns." 30 Other circuinstances, however, require greater deference toward prison officials. During a prison disturbance, for example, prison officials inust consider not only the risk of harm to the inmate against whom force is used, but also the risk of harm to others if officials do not control the disturbance. The Supreme Court concluded that when prison officials use force to resolve a disturbance that "indisputably poses significant risks" to prison security, "the question whether the measure taken inflicted unnecessary and wanton pain and suffering ultimately turns on 'whether force was applied in a good faith effort to maintain or restore discipline or mahciously and sadistically for the very purpose of causing harm.' "31 The Court suggested that factors relevant to this threshold determination include " the need for the application of force, the relationship between the need and the amount of the force that was used, [and] the extent of injury inflicted." "'32

Although Whitley applies the Johnson factors to defeat a prisoner's excessive force claim, this is the Supreme Court's only application of the Johnson factors in a section 1983 case. Moreover, the Supreme Court's explanation of when and how a court can apply those factors to a prisoner's excessive force claim differs noticeably from the circuit courts' mechanical application of those factors to every claim. Whitley requires a bifurcated inquiry, permitting consideration of "malice" only when other "equally important governmental responsibilities"- such as an official's duty to ensure prison security-clash with a prisoner's eighth amendment rights. As the Umited States Court of Appeals for the Eighth Circuit recently recognized in Wyatt $v$. Delaney, ${ }^{33}$ equally inportant governinental responsibilities are not present im all excessive force cases. ${ }^{34}$

30. Id. In these cases, the appropriate standard would be one like the "deliberate indifference" standard articulated in Estelle v. Gamble, 429 U.S. 97, 10405 (1976).

31. 475 U.S. at 320-21 (quoting Johnson v. Glick, 481 F.2d 1028, 1033 (2d Cir.), cert. denied, 414 U.S. 1033 (1973)).

32. Id. at 321 (quoting Johnson, $481 \mathrm{~F} .2 \mathrm{~d}$ at 1033).

33. 818 F.2d 21, 23 (8th Cir. 1987) (when case does not involve prison security ineasure undertaken to resolve prison disturbance, court should not apply inalice factor).

34. See, e.g., McRorie v. Shimoda, 795 F.2d 780 (9th Cir. 1986). In McRorie, a prison guard stripsearched an inınate after a shakedown searcl. The guard ordered the inmate to spread lis legs apart and tapped the inside of the innnate's thigh with a riot stick. When the innate involuntarily giggled, the guard responded "you think that's funny, liuli?" and attenpted to plunge the riot stick into the inınate's anus. Id. at 781-82.

Whitley requires heightened deference to the judgment of prison officials when "a prison security measure is undertaken to resolve a disturbance ... that indisputably poses significant risks to the safety of inınates and prison staff," 475 U.S. at 320 , or when the " "ever-present potential for violent confrontation and conflagration' ... ripens into actual unrest and conflict," id. at 321 (quoting Jones v. North Carolina Prisoners' Labor Uirion, Inc., 433 U.S. 119, 132 (1977)). As McRorie deinonstrates, these exigent circuinstances are not present in every excessive force case. 
Wyatt underscores the Court's recognition that the Johnson "malice" inquiry is not necessary or appropriate in every excessive force case implicating eightlı amendment rights. ${ }^{35}$

\section{III}

The circuits also have applied the Johnson factors to all section 1983 claims by persons subjected to force during an arrest or investigatory stop. Whereas Whitley demonstrates that courts slould sometimes, but not always, apply the Johnson factors to a prisoner's excessive force claim, the Supreme Court's fourtl amendment jurisprudence estabhishes that courts sliould never apply all of the Johnson factors to excessive force claims arising from an arrest or investigatory stop.

The fourth amendment provides citizens witl a riglit to be secure im their persons from unreasonable seizures. This right protects an individual's "legitimate expectations that in certam places and at certam times he has 'the right to be let alone." "36 In Terry v. Ohio, ${ }^{37}$ the Supreme Court acknowledged the breadtl of this riglit in defining when a "seizure" occurs. The Court recognized that a seizure of the person includes any conduct that "by means of physical force ... lias in some way restrained the liberty of a citizen." 38

Terry states a broad notion of what constitutes a seizure-one that compels the conclusion that "any apphication of physical force to a citizen which lias the effect of disabling him pliysically to any extent" is a

35. The United States Court of Appeals for the Fourth Circuit has mischaracterized Whitley's holding. In Graham v. City of Charlotte, 827 F.2d 945 (4th Cir. 1987), the court stated that Whitley stands for the proposition that an excessive force claim arising under the eighth amendment ultimately turns on the presence or absence of malice or sadism by prison officials. Id. at 948 n.3. The Graham court thus characterized the Johnson malice factor as "central" to an eighth amendment excessive force claim. Id. This conclusion is incorrect. As Whitley reiterated, the central factor of an eighth amendment excessive force claim is the unnecessary and wanton infliction of pain. If prison officials apply force in response to a legitimate risk to prison security, the officials' good or bad faith is relevant-indeed central-under Whitley. The Fourth Circuit's position in Graham presumes that this will always be the case. As suggested supra note 34, however, prison officials do not always apply force in response to legitimate prison security concerns. In these instances, the officers' motives are irrelevant.

In a recent opinion by Justice Powell (sitting as a Circuit Judge), another panel of the Fourth Circuit held that a "deliberate indifference" standard is appropriate when there is no clash between a prisoner's needs or rights and "equally important governmental responsibilities." Lafaut v. Smith, 834 F.2d 389, 392 (4th Cir. 1987) (holding that failure of prison officials to provide proper toilet facilities for paraplegic inmate violaled eighth amendment). Though not an excessive force case, Lafaut recognizes that some exigency of circumstances is necessary before applying Whitley's malice standard.

36. Winston v. Lee, 470 U.S. 753, 758 (1985) (quoting Olmstead v. Umited States, 277 U.S. 438, 478 (1928) (Brandeis, J., dissenting)).

37. 392 U.S. 1 (1968).

38. Id. at 19 n.16. 
seizure. ${ }^{39}$ The apphication of force implicates a person's fourth amendment right whenever that person mamtams a reasonable expectation of privacy $\mathrm{m}$ his bodily imtegrity that protects him from such imtrusion. ${ }^{40} \mathrm{~A}$ claim that an officer applied excessive force during an arrest or stop therefore raises a potential violation of the fourth amendment's prohibition against unreasonable seizures.

The Supreme Court reinforced the breadth of the notion of "seizure" in addressing the excessive force claim presented in Tennessee v. Garner. ${ }^{41}$ Garner involved an unarmed fifteen-year old burglary suspect who was shot and killed by the police as he attempted to flee. The suspect's parents filed a section 1983 claim against the pohice officers, the police department and the city of Memphis. In evaluating the claim, the Court stated that "there can be no question that apprehension by the use of deadly force is a seizure subject to the reasonableness requireinent of the Fourtl Amendment." 42 The Court then balanced " "the nature and quality of the intrusion on the individual's Fourth Amendment interests" "43 (bemg accosted by the use of deadly force) against the harm that would have occurred without the use of force (the escape of an unarmed nondangerous suspect). ${ }^{44}$ The Court concluded that the use of deadly force to apprehend a nondangerous suspect violates the fourth amendment. ${ }^{45}$

The claim in Garner was that the pohce applied excessive force against Garner in violation of his constitutional rights. Yet nowhere in the opimion did the Court mention substantive due process or the Johnson factors. ${ }^{46}$ This ormssion is easily understandable in light of the fourth amendment's reasonableness standard. The fourtli amendment simply is not concerned with the severity of a plaintiff's injuries. ${ }^{47}$ Nor is the fourth amendment concerned, as a threshold matter, with whetler an officer acted "in a good faith effort to maintain or restore discipline or

\footnotetext{
39. Justice v. Dennis, 834 F.2d 380, 388 (4th Cir. 1987) (en banc) (Phillips, J., dissenting).

40. See, e.g., Winston, 470 U.S. at 767 (1985).

41. 471 U.S. 1 (1985).

42. Id. at 7 .

43. Id. at 8 (quoting United States v. Place, 462 U.S. 696, 703 (1983)).

44. Id. at 8-11.

45. Id. at 11.

46. The Sixth Circuit had held the statute invalid under the due process clause as well as the
} fourth amendment. Garner v. Memphis Police Dep't, 710 F.2d 240, 246-47 (6th Cir. 1983), aff'd, 471 U.S. 1 (1985).

47. Lester v. City of Chicago, 830 F.2d 706, 712 (7th Cir. 1987). The severity of the plaintiff's injury is of course relevant to the issue of damages, but only after a fourth amendment violation is established. 
maliciously and sadistically for the purpose of causing harm."48 As the Supreme Court held in Scott $v$. United States, ${ }^{49}$ the existence of a fourth amendment violation depends wholly upon "an objective assessment of [an] officer's actions in light of the facts and circumstances confronting him at the time."so An officer's subjective good faith affords him no comfort if that objective assessment reveals that his conduct was unreasonable. Similarly, the officer's overt malice or sadisin does not make his actions unconstitutional if those actions were justified by the facts present at the time he acted. No Supreme Court decision has suggested that "malice" is relevant to the determination of whether an officer violated the fourth amendment. 51

Applying the Johnson standard to every excessive force claim imphcating fourth amendment rights can produce inexplicable results, as is demonstrated by applying that standard to the claim presented im Garner. The officers in Garner did not act mahiciously and sadistically for the very purpose of causing Garner harm. Instead, they acted in good faith reliance on a Tennessee statute that authorized the use of deadly force agamst fleeing felons. ${ }^{52}$ Under the Johnson standard, a decisionmaker would consider the officers' good faith and could conclude

48. Johnson v. Glick, 481 F.2d 1028, 1033 (2d Cir.), cert. denied, 414 U.S. 1033 (1973). While an officer's objective good faith is relevant to the applicability of the exclusionary rule, United States v. Leon, 468 U.S. 897, 918-23 (1984), it is not relevant to the question whether a fourth amendment violation has occurred.

49. 436 U.S. 128 (1978).

50. Id. at 136.

51. One recent decision suggested that Johnson's characterization of force that is applied "maliciously and sadistically for the very purpose of causing harm" may merely describe conduct that is objectively unreasonable, rather than establish malice as a prerequisite to the existence of a constitutional violation. Justice v. Dennis, 834 F.2d 380, 383 (4th Cir. 1987) (en banc). Certainly it is often true that force that is applied in bad faith is objectively unreasonable as well, but this is not necessarily true. Force that is applied for illegitimate reasons may yet be entirely reasonable under the circumstances. See infra note 104. Likewise, force that is applied with good faith may still be objectively unreasonable. See infra notes $52-53$ and accompanying text. In short, a court can determine whether an officer complied with the fourth amendment without any examination of the officer's subjective motivation.

As a result, requiring a decisionmaker to consider an officer's good or bad faith pollutes the proper analysis of excessive force claims. When jurors receive the boilerplate excessive force instruction, they are told that they must consider whether force was applied "in a good faith effort to maintain or restore discipline or maliciously and sadistically for the very purpose of causing harm." The average juror hears this and concludes: "If the officer acted in good faith, it must have been constitutional. If the officer acted in bad faith and meant to hurt the plaintiff, it must have been unconstitutional." Such a conclusion is simply wrong under any rational reading of the Court's fourth amendment decisions.

52. The statute provided that "[i]f, after notice of the intention to arrest the defendant, he either flee or forcibly resist, the officer may use all the necessary means to effect the arrest." TENN. CODE ANN, § 40-7-108 (1982) (current version at TENN. CODE ANN. § 40-7-108 (1987 Supp.)). The Court held that the statute was unconstitutional inasmuch as it authorized the use of force against suspects such as Garner. Garner, 471 U.S. at 11, 20-21. 
that the officers did not violate Garner's constitutional rights. Yet the Supreme Court, faced with these very facts, decided that the officers without doubt violated Garner's constitutional rights. Consideration of the Johnson factors therefore allows the decisionmaker to short-circuit the fourth amendment's objective inquiry and bestows upon officials a potential subjective good faith immunity that the Supreme Court repeatedly has held they do not possess. ${ }^{53}$

Whitley and Garner provide the federal courts with clear guidance regarding the standards for evaluating the excessive force claims of prisoners and persons subjected to an arrest or investigatory stop. The Supreme Court, however, has not yet faced the question of what standards are appropriate for evaluating the excessive force claims of pretrial detainees. Most authorities have maintained that the due process clause is the proper vehicle for analyzing a pretrial detainee's excessive force claim. ${ }^{54}$ A detainee's interest in bodily privacy and integrity is coterminous with an ordinary citizen's, however, so one rightly can wonder why the fourth amendment should not also protect detainees from excessive force.

Since a reasonable officer at the time of the shooting would not have known of the statute's infirmity, however, the officers were entitled to qualified immunity from liability for damages. See Garner, 600, F.2d at 54. This immunity arises not because the officers acted with subjective good faith, but because at the time of the shooting it was not clearly established that such a shooting would violate Garner's rights. See Mitchell v. Forsyth, 472 U.S. 511, 525-35 (1985); Harlow v. Fitzgerald, 457 U.S. 800, 815-19 (1982).

53. See supra note 52 .

54. See, e.g., Justice v. Dennis, 834 F.2d 380 (4th Cir. 1987) (en banc); Johnson, 481 F.2d at 1033; see also cases cited supra note 20. But see Justice, 834 F.2d at 383 (Philhps, J., dissenting).

One commentator has characterized Bell v. Wolfish, 441 U.S. 520 (1979), as holding that the due process clause is the proper textual source of protection from excessive force for detainees. Comment, Excessive Force Claims: Removing the Double Standard, 53 U. CHI. L. REv. 1369, 1375$76,1387-88$ (1986). This characterization is incorrect. Wolfish was a class action challenging various conditions of pretrial detention. None of those conditions involved the use of serious physical force. The conditions of detention (double-bunking of inmates, for example) that implicated "only the protection against deprivation of liberty without due process of law," Wolfish, 441 U.S. at 535 (empliasis added), were analyzed solely under the due process clause. In contrast, other conditions of detention (shakedown searches, strip searches, and visual body cavity searches) implicated detainees' fourth amendment privacy interests as well. The Court analyzed these conditions under the fourth amendment before addressing any due process challenge. Id. at 555-60. Correctly viewed, Wolfish stands for the proposition that the constitutionality of official conduct is determined in the first instance by reference to the primary constitutional riglit implicated by that conduct. As stated infra notes 55-78 and accompanying text, Supreme Court precedent seems to suggest that the use of serious physical force against a detainee primarily implicates his fourth amendment interests in freedom from bodily intrusions. 
Excessive force decisions have identified two types of pretrial detainees-one whose arrest has been completed but who is not confined in a prison cell and one who is held in a cell pending trial. The circuits have held that excessive force against the first type of detainee-one who is not detained in a cell-only implicates his rights under the due process clause. The Supreme Court, however, has recognized that the fourth amendment does not cease to apply simply because an arrest is complete. In both Schmerber v. California ${ }^{55}$ and Winston v. Lee ${ }^{56}$ the suspect's arrest already had been effected prior to the challenged physical intrusions, ${ }^{57}$ yet in each case the Court applied the fourth amendment's reasonableness standard to judge the constitutionality of the state's conduct. ${ }^{58}$ These decisions demonstrate that the fourtl amendment is not concerned with whether an excessive force plaimtiff was an "arrestee" or a "detainee." 59 Rather, as Winston recognized, the fourth amendment is concerned with whether a citizen has been subjected to "unreasonable governmental intrusions into any area im which lie lias a reasonable expectation of privacy." 60 If the citizen lias been subjected to such intrusions, those intrnsions are unconstitutional regardless of the citizen's status.

The Supreme Court's broad definition of "seizure" in Terry and Garner surely encompasses the purposeful use of force agamst this type detainee. As Judge Pliillips recognized in dissenting from the en banc decision of the United States Court of Appeals for the Fourtl Circuit in Justice v. Dennis: 61

55. 384 U.S. 757 (1966) (police-ordered extraction of blood from drunk-driving suspect).

56. 470 U.S. 753 (1985) (court-ordered surgery to remove bullet for evidentiary purposes).

57. Schmerber, 384 U.S. at 758 (blood drawn after arrest at hospital); Winston, 470 U.S. at 75557 (suspect liad been charged; surgery sclieduled three months later).

58. Schmerber, 384 U.S. at 766-72; Winston, 470 U.S. at 758-66.

59. As a policy matter, it is unclear why a person's status as an "arrestee" or "detainee not in a jail cell" should make any difference in the constitutional inquiry. One commentator who correctly recognized that Garner governs arrest-related excessive force claims made the following observations:

[C]riticisms leveled at due process scrutiny seem no less compelling in the detainment context thian in the arrest context. In fact, one must ask furtlier why suspects during arrests are protected (by the fourth amendment) against "unreasonable" conduct, wlile detainees receive protection only against "malicious" or "shocking" conduct under the due process test. In some ways, it would seem, the arrest standard slould be more deferential thian the detainment standard. The exigencies of arrest and the need to defer to an officer's judgment in a quickly developing situation are indisputably diminislied in the detainment context; there is no apparent reason for affording tle officer greater discretion in that context.

Comment, supra note 54, at 1389 . Moreover, distinguishing between an "arrestee" and a "detainee" requires courts to make the often metaphysical determination of precisely when an arrest is complete. For an example of the difficulty and abstraction involved in this determintion, see Justice $\mathbf{v}$. Dennis, 834 F.2d 380, 383 (4th Cir. 1987) (en banc) (Phillips, J., dissenting).

60. Winston, 470 U.S. at 767 (emphasis added).

61. 834 F.2d at 383 (Phillips, J., dissenting). 
Terry v. Ohio has long since settled that a "seizure" of the person within the fourth amendment's meaning is not limited to conduct that constitutes a "technical arrest," and instead encompasses any conduct that "by means of physical force . . . has in some way restrained the liberty of a citizen." It would be a strange doctrinal twist indeed that treated as "seizures" the limited intrusions, without any use of physical force, that are routinely now considered "Terry stops," but did not treat as a "seizure" the direct use of physical force in subduing a person in custody just because his "arrest" had already been effected. I am satisfied that it is a twist not present in controlling fourth amendment doctrine. Rather, it seems obvious to me that within Terry's analysis any application of physical force to a citizen which has the effect of disabling. him physically to any extent is a "restraint on his liberty," leaving only the question of its reasonableness. ${ }^{62}$

The second type of pretrial detainee is a person who is held in a cell pending trial. The Supreme Court has noted that this type of detainee does not possess "the full range of freedoins of an unincarcerated individual."63 Gratuitous language in the Court's prison search decisions, however, has created the impression that pretrial detainees in prison cells retain no fourth amendment rights at all.

In Bell v. Wolfish, ${ }^{64}$ the Court rejected a fourth amendment challenge by pretrial detamees to jail rules authorizing random cell searches and visual body cavity searches. ${ }^{65}$ The Court merely assumed without deciding that a pretrial detainee in a prison cell retamed a "diminished expectation of privacy" from such practices. ${ }^{66}$ The Court revisited the issue of privacy im prison cells, however, in Hudson v. Palmer. ${ }^{67}$ In Hudson, a convicted prisoner had filed a section 1983 action clainimg that a search of his cell and seizure of his property discovered during the search violated the fourth amendnient. The Court rejected the inmate's claim, stating that "society is not prepared to recognize as legitimate any subjective expectation of privacy that a prisoner might have in his prison cell."68 The Court thus held that "the Fourth Amendment proscription against unreasonable searches does not apply within the confines of the prison cell."69 The Court also rejected, for similar reasons, the inmate's claim that the seizure of his property was unreasonable. ${ }^{70}$ Fron these

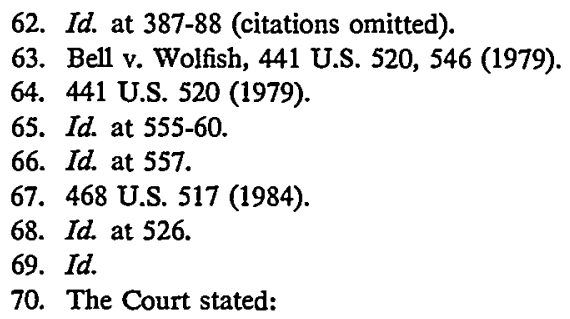

[T] against unreasonable searches is inapplicable in a prison cell, apply with controlling force 
premises, the Court concluded that "the Fourth Amendment has no applicability to a prison cell." 71

Hudson's broad statements could lead one to conclude mistakenly that the fourth amendment does not protect jailed detainees from excessive force. It is true that shakedown searches of a cell and the seizure of property in that cell do not violate the fourth amendment. That is true, however, not because the fourth amendment never applies in a cell, but because a detainee's expectation of privacy in his cell and possessions is always outweighed by the state's interest in institutional security. ${ }^{72}$ The detainee's expectation of privacy is therefore not "legitimate" and is unworthy of fourth amendinent protection. ${ }^{73}$ This is quite different from the proposition that the fourth amendinent never applies within the confines of a cell, however, for to say that a detainee has no legitimate expectation of privacy from a shakedown search differs froin saying that he has no legitimate expectation of privacy from an arbitrary beating.

The Court in Wolfish and Hudson simply did not have to decide whether a person in a cell retains any legitimate expectation of privacy in his bodily integrity that protects him from severe physical intrusions such as excessive force. The question is of no importance in the case of prisoners, because they are protected by the eighth amendment's prohibition on cruel and unusual pumshment. ${ }^{74}$ Detainees, however, do not enjoy the protections of the eighth amendinent. ${ }^{75}$ To hold that the fourth

to seizures. Prison officials must be free to seize from cells any articles which, in their view, disserve legitimate institutional interests.

Id. at 528 n.8.

71. Id. at 536 .

72. See id. at 526-28.

73. Id. at 530 .

74. Whitley v. Albers, 475 U.S. 312, 327 (1986) ("[T]he Eighth Amendment, which is specifically concerned with the unnecessary and wanton infiiction of pain in penal institutions, serves as the primary source of substantive protection to convicted prisoners in cases ... where the deliberate use of force is challenged as excessive and unjustified.").

One rightly can wonder why a prisoner should not also retain a reasonable expectation of privacy in his bodily integrity and therefore enjoy fourth amendment protection from excessive physical force in cases in which prison officials have no legitimate puritive or disciplinary purpose for using force. Cf. Johnson v. Glick, 481 F.2d 1028, 1032 (2d Cir.) ("[A]lthough a spontaneous attack by a guard is 'cruel' and, we hope, 'unusual,' it does not fit any ordinary concept of punishment."), cert. denied, 414 U.S. 1033 (1973). It seems logical to treat these instances of force as seizures rather than punishment. This would make little practical difference, however, because heightened deference to prison officials is unnecessary under Whitley when the force has no legitimate punitive or disciplinary purpose. In such a case, an eighth amendment standard like the Estelle "deliberate indifference" standard is required, and in practice such a standard would be almost indistinguishable from the fourth amendment's reasonableness inquiry. In any event, the Court is quite unlikely to reconsider the issue of excessive force against prisoners when the ink on Whitley is scarcely dry.

75. Ingraham v, Wright, 430 U.S. 651, 671 n.40 (1977) ("Eighth Amendment scrutiny is appropriate only after the State has complied with the constitutional guarantees traditionally associated with criminal prosecutions."). 
amendment never protects a detamee im a prison cell, one must conclude that society is not prepared to recognize that a detainee retains any legitimate expectation of privacy from unwarranted force. Under such a rule, the arbitrary or excessive use of force against a detainee would always be a warranted, reasonable intrusion free from any fourth amendment scrutiny.

Though the Supreme Court has not addressed the question, one would suspect that the Court would hesitate to conclude that a jailed detainee retains absolutely no legitimate expectation of privacy in his bodily integrity. In Winston v. Lee, ${ }^{76}$ the Court applied the fourth amendment to strike down an order compelling a suspect to undergo surgery to remove a bullet for its possible evidentiary use. If jailed detainees have no legitimate expectation of privacy in their bodily integrity, state officials could take a suspect such as the one in Winston, detain him im a cell and remove the bullet from his body without benefit of anesthesia, yet not even implicate his fourth amendment rights. Winston made clear that a person outside of a cell maintains a legitimate expectation of privacy in his bodily integrity that protects him from such an intrusion. It is hard to imagine why that expectation of privacy should becoine illegitimate simply because the person is placed im a cell. While concerns of institutional security will sometimes outweigh a detamee's expectation of freedom from physical force, they will not do so in every case. ${ }^{77}$ Courts therefore should not conclude that jailed detamees retain no legitimate expectation of freedom from severe physical intrusions. Instead, courts should analyze a detainee's excessive force claim under the fourth amendment's reasonableness standard, allowing due deference to state officials when exigencies of institutional security are present..$^{78}$

\section{$\mathrm{V}$}

Recently, in Lester v. City of Chicago, ${ }^{79}$ the United States Court of Appeals for the Seventh Circuit became the first federal court to reject the substantive due process inquiry derived from Johnson. The plaintiff

76. 470 U.S. 753 (1985).

77. Suppose, for example, that the prisoner in McRorie v. Shimoda, 795 F.2d 780 (9th Cir. 1986), see supra note 34 , had been a detainee. Concerns of institutional security would not have outweighed McRorie's expectation of privacy from having a riot stick rammed into his anus merely because he involuntarily giggled during a stripsearch.

78. Where exigencies of institutional security are present, the fourth amendment standard would allow state officials greater latitude in using force in response to those exigencies. Under the Garner balancing test, as the "importance of the governmental interests alleged to justify the intrusion" increases, the more serious "the nature and quality of the intrusion" can be without being unreasonable and violating the fourth amendment. Tennessee v. Garner, 471 U.S. 1, 8 (1985).

79. 830 F.2d 706 (7th Cir. 1987). 
in Lester had filed a section 1983 action claiming that officers used excessive force while arresting lier. The district court instructed the jury in accordance with the Seventh Circuit decision in Gumz v. Morrissette. ${ }^{80}$ Gumz had held that an officer's use of force is unconstitutional if it causes severe injuries, is grossly disproportionate to the need for the force and is inspired by inalice rather than inerely careless or unwise excess of zeal. ${ }^{81}$ The jury, considering each of these factors, returned a verdict in favor of the officers.

The Seventh Circuit reversed, concluding that "the proper standard for analyzing excessive force in arrest claims is a Fourth Amendment standard, and not a Fourteenth Amendinent substantive due process standard." 82 This is so, saicl the court, because "the Fourth Amendment, unlike the Fourteenth Amendinent, is specifically directed to unreasonable seizures." ${ }^{83}$ The court rejected the suggestion that the Gumz/Johnson factors merely restated fourth ainendment analysis, notmg both that the malice criterion is inconsistent with the objective reasonableness standard and that a seizure ean be unreasonable without causing serious injury. ${ }^{84}$ Having recognized the incompatibility of substantive due process and fourth ainendinent analysis, the court concluded that "there should be no occasion to apply substantive due process standards ... to an excessive force in arrest claim." 85

The Lester court limited its holding to arrest-related excessive force claims, specifically reserving the question whether substantive due process retained vitality in other contexts. ${ }^{86}$ The rationale of Lester, however, casts doubt upon the theoretical justification for continued substantive due process analysis of any excessive force claim. This doubt is well-founded when one examines why the Johnson court initially adopted the substantive due process standard. This examination-enlightened by intervening Supreme Court developinents-leads to the conclusion that the unreflective adherence to substantive due process has flawed the analysis of excessive force claims.

Two plausible rationales could have supported the Johnson court's adoption of a substantive due process standard. One explanation is the court's apparent belief that the due process clause provided protection from police brutality that was broader in scope than that provided by

80. 772 F.2d 1395 (7th Cir. 1985), overruled, Lester v. City of Chicago, 830 F.2d 706, 713 (7th Cir. 1987).

81. 772 F.2d at 1400 .

82. Lester, 830 F.2d at 710 .

83. Id. at 712 .

84. Id. at $712-13$.

85. Id. at 713.

86. Id. at $713 \&$ n.7. 
other amendments. ${ }^{87}$ Under this rationale, Johnson stands for the proposition that the due process clause provides one's primary source of constitutional protection from excessive force. The other explanation is that the Johnson court, relying on the weight of prior authority, beheved that the plaintiff's status as a pretrial detainee made it impossible to analyze his claim under the fourth or eighth amendment. ${ }^{88}$ Faced with a plaintiff who clearly had been wronged, the Johnson court used what it thought was the only available tree from which to hang the responsible officialRochin's substantive due process standard.

Intervening developinents, however, have undercut these rationales. When the Supreme Court decided Rochin, the fourth amendment did not yet apply to the states. Without the due process clause, the Court would have been powerless to control intrusive police practices such as stomach-pumping. Since the Supreme Court held that the fourtli amendment applies to tlie states, ${ }^{89}$ lowever, the Court has never again used Rochin to analyze the constitutionality of physically intrusive official conduct. Instead, the Court has looked solely to the fourth amendinent-or, in the case of prisoners, to the eiglith-to determine the constitutionality of serious physical intrusions. 90

Moreover, the Court has rejected the recurring suggestion that the due process clause provides one's primary source of protection from intrusive searches and seizures. As previously mentioned, the Court applied the fourth annendment in Winston $v$. Lee ${ }^{91}$ to forbid a state from coinpelling a suspect to undergo surgery to reinove a bullet for use as evidence of the suspect's guilt. In United States v. Montoya de Hernandez, ${ }^{92}$ the Court applied the fourtli amendment to uphold the extended detention of a suspected "alimentary canal" smuggler in order to

87. The Johnson court stated:

[C]onstitutional protection against police brutality is not limited to conduct violating the specific command of the Eighth Amendment or ... of the Fourth. Roclim v. California must stand for the proposition that, quite apart from any "specific" of the Bill of Riglits, application of undue force by law enforcement officers deprives a suspect of liberty without due process of law.

481 F.2d at 1032 (citations omitted). It is unclear whetler the Johnson court felt bound by Rochin to rcach this conclusion or whether the court instead extrapolated this conclusion from Rochin's general discussion. In eitler event, Johnson clearly recognized the due process clause as the primary source of constitutional protection from excessive force.

88. The Johnson court stated that "most of the courts faced witl challenges to the conditions of pre-trial detention have primarily based their analysis directly on the due process clause." Id. at 1033.

89. Mapp v. Oliio, 367 U.S. 643,655 (1961).

90. See, e.g., United States v. Montoya de Hernandez, 473 U.S. 531, 538-41 (1985); Tennessee v. Garner, 471 U.S. 1, 7-12 (1985); Winston v. Lee, 470 U.S. 753, 758-66 (1985); Sclimerber v. California, 384 U.S. 757, 766-72 (1960).

91. 470 U.S. $753,763-66$ (1985).

92. 473 U.S. $531,541-44$ (1985). 
examine her feces for drugs. In Winston and Montoya, as well as in Garner, the Court ignored the due process clause, forsaking Rochin in favor of fourth amendment analysis. ${ }^{93}$

The Court's disfavor with substantive due process analysis of physical intrusions has not been merely implicit. In Whitley, the Court explicitly rejected the suggestion that the due process clause provided a convict's primary source of protection from excessive force. Because the eighth amendment "is specifically concerned with the unnecessary and wanton infliction of pain in penal institutions," the Court concluded that the eighth amendinent "serves as the primary source of substantive protection to convicted prisoners in cases . . . where the deliberate use of force is challenged as excessive and unjustified." 94 Whitley recognizes that the due process clause--assuming that indeed it lias substantive content ${ }^{95}$-provides protection that is at best duplicative of that provided by the eighth amendment. 96

In liglt of these developments, there exists no need for substantive due process analysis of excessive force claims. On the one hand, the Court's excessive force decisions suggest that if the use of force violates the fourth or eighth amendment, any protection provided by the due process clause is merely duplicative. On the other liand, if the use of force does not transgress the fourth or eightl amendinent, then the Supreme Court's decision in Baker v. McCollan ${ }^{97}$ suggests that no due process violation occurs. In Baker, the Court faced a plaintiff's section 1983 claim that his detention over a weekend pursuant to a facially valid warrant deprived him of liberty without due process of law. The Court rejected this claim, holding that the government's compliance witl the fourth amendment accorded the plaintiff due process. ${ }^{98}$ Baker thus suggests that when officials apply physical force without transgressing the standards of the fourth or eighth amendinent, they have not deprived the object of that force of liberty without due process of law.

93. Winston mentioned Rochin only in a footnote. 470 U.S. at 762 n.5. Neither Montoya nor Garner mentioned Rochin.

94. 475 U.S. at 327 (emphasis addled).

95. Several federal judges have argued vehemently that the due process clause does not possess substantive content in this context. See Gilmere v. City of Atlanta, 774 F.2d 1495, 1510-11 (11th Cir. 1985) (en banc) (Tjoflat, J., dissenting in part, joined by Roney and Fay, JJ.), cert. denied, 476 U.S. 1115 and 476 U.S. 1124 (1986); Gumz v. Morrissette, 772 F.2d 1395, 1404-09 (7th Cir. 1985) (Easterbrook, J., concurring in the judgment), overruled, Lester v. City of Chicago, 830 F.2d 706, 713 (7th Cir. 1987).

96. 475 U.S. at 327.

97. 443 U.S. 137 (1979).

98. Id. at $142-46$. 
VI

Despite these developinents, the circuits have continued almost without exception to apply all of the Johnson substantive due process factors to every excessive force claim, regardless of whether that claim actually implicates a fourth or eighth amendment right. This blind adlierence to substantive due process has resulted in the creation of an abstract constitutional right to be free of excessive force. This "right"defined and protected solely by the Johnson standard-has becoine distinct froin any specific constitutional guarantee.

This point is best deinonstrated by the inajority opimion of the Umited States Court of Appeals for the Fourth Circuit en banc in Justice v. Dennis. 99 Justice involved a drunk driving suspect who filed a section 1983 action claiming that the arresting officers applied excessive force against him in the stationhouse following his arrest. The district court instructed the jury to consider all of the Johnson factors, and the jury returned a verdict in favor of the officers. In rejecting the plaintiff's appeal, the Fourth Circuit majority stated:

Courts, including our own, have experienced soine difficulty in defining the scope of hability for excessive force as a constitutional tort under section 1983. The dilemma has been coinplicated by the fact that clains of excessive force may arise in the context of the fourth, eiglith, or as in this instance, the fiftl amendment. Subtle efforts at distinction are, therefore, coinmon in cases in this area.

There are, nevertheless, certain basic principles in section 1983 jurisprudence as it relates to clains of excessive force that are beyond question. ${ }^{100}$

The Justice inajority concluded that the Johnson substantive due process factors, as incorporated in the jury instructions, "fairly and adequately state[d] the pertinent legal principles involved" " in evaluating excessive force claims. ${ }^{101}$

Justice thus requires the decisionmaker to consider in every instance whether the force was applied maliciously and sadistically for the very purpose of causing larm and whether the force caused serious injuries, even though the use of force implicates rights to whicli the fourth or eighth amendment is specifically addressed. This is nothing more than the creation and application of an abstract constitutional right to be free of excessive force. For the lyypothetical plaintiff set forth at the beginning of this coininent ${ }^{102}$ to recover on his constitutional claim, he could

99. 834 F.2d 380 (4th Cir. 1987) (en banc).

100. Id. at 382 (citation omitted). Presumably when the Justice court said "fifth amendment," it meant "fourteenth amendment."

101. Id. at 383 (quoting Chavis v. Finnlines Ltd., 576 F.2d 1072, 1076 (4th Cir. 1978)).

102. See supra text following note 2 . 
not merely demonstrate a violation of his fourth amendment rights as defined by the objective standards of Garner, Winston and Terry. Instead, he would have to demonstrate a violation of his "right" to be free of excessive force as defined by the Johnson/Justice "basic principles of section 1983 jurisprudence." 103

Try as one might to find it, there is no authority in Supreme Court precedent for an abstract, uniform constitutional right to be free of excessive force. As Garner and Whitley indicate respectively, citizens have a specific right to be free of force that constitutes an unreasonable seizure and prisoners have a specific right to be free of force that constitutes cruel and unusual punishment. These different rights are protected by independent constitutional standards. Moreover, neither of these standards requires all plaintiffs to denionstrate that officials caused serious injury and acted maliciously and sadistically for the very purpose of causing harm. The circuits' continued application of the Johnson factors therefore constitutes a perverse sort of judicial activism. The circuits have fashioned an abstract right to be free of excessive force, yet have fashioned a standard to protect that right that is inconsistent with, and often more restrictive than, the standards protectimg the specific constitutional right implicated by the use of force. ${ }^{104}$

One can scarcely impugn the desire of the federal courts-who are faced with a growing torrent of excessive force cases-to fashion rules that discourage frivolous excessive force claims. As circuit courts have recognized, not every push or shove by a state official violates the Consti-

103. Justice, 834 F.2d at 382 . The Justice majority seems to have overlooked the Supreme Court's admonition in Baker v. McCollan, 443 U.S. 137 (1979), that there are no basic principles of section 1983 jurisprudence. Section 1983 does not create any substantive rights; it merely creates an express right to sue to vindicate already defined federal or constitutional rights. Id. at 144 n.3. Instead, principles of constitutional jurisprudence-fourth and eighth amendment jurisprudencegovern constitutional decisionmaking in excessive force cases and courts must apply these principles when a plaintiff brings an excessive force claim under section 1983.

104. It bears noting, however, that while the Johnson malice standard may operate to defeat meritorious excessive force claims, it can also operate less restrictively than a purely objective reasonableness standard. Assume, for exarnple, that a police officer is pursuing a murder suspect. The suspect turns and begins to fire upon the officer. A reasonable officer in this position likely could, depending upon the surrounding circumstances, use deadly force to subdue the suspect without violating the fourth amendment. Suppose an officer being fired upon, however, decides to use deadly force not because the suspect is firing upon him but rather because the suspect is black and the officer hates blacks. The officer's action-using deadly force-remains objectively reasonable and Garner suggests that this should be the end of the excessive force inquiry. Yet under the Johnson standard, a jury could return a verdict against the officer on these facts, since he clearly acted with malice for the very purpose of causing harm. The Johnson standard thus creates the unfortunate possibility of plaintiffs being able to raise issues, such as an officer's racist or sadistic motivations or prior bad acts, that are irrelevant to a proper fourth ainendment inquiry. 
tution. ${ }^{105}$ This statement, however, is not a premise for heightening the constitutional burden on excessive force plaintiffs, but rather is the natural conclusion of the proper constitutional inquiry. The price of having constitutional protection from physical intrusion is that every push or shove by a state officer is a potential constitutional violation, depending upon whether it transgresses the proper constitutional standards. The Supreme Court has not seen fit to immunize law enforcenent officials froin the adverse consequences of this constitutional determination based on those officials' pure hearts. Certainly, federal courts should not be flooded with meritless excessive force cases. Equally certainly, federal courts are capable of fashioning rules that discourage meritless cases without undermining the integrity and consistency of constitutional standards.

\section{VII}

Johnson v. Glick 106 first adopted substantive due process analysis of excessive force claims based on the Suprene Court's Rochin v. California ${ }^{107}$ decision and the perceived inapplicability of the fourth or eighth amendment. Subsequent Supreme Court decisions have forsaken Rochin's substantive due process analysis of physically intrusive government conduct. Those decisions suggest that courts should judge the constitutionality of physical force by applying the standard developed to protect the specific fourth or eighth amendinent right implicated by the use of force. The courts' continued adherence to the Johnson standard despite these developinents has flawed the analysis of excessive force claims, particularly those implicating fourth amendment rights. Courts should therefore abandon the Johnson approach in excessive force cases. In cases involving prisoner claims, courts should faithfully comply with the bifurcated inquiry of Whitley $v$. Albers. ${ }^{108}$ In all other excessive force cases, courts should apply the fourth amendment's objective reasonableness standard as elaborated in Tennessee v. Garner ${ }^{109}$ and the Supreine Court's other fourth ainendment decisions.

105. See, e.g., Graham v. City of Charlotte, 827 F.2d 945, 949-50 (4th Cir. 1987); Johnson v. Glick, 481 F.2d 1028, 1033 (2d Cir.), cert. denied, 414 U.S. 1033 (1973).

106. 481 F.2d 1028, 1032-33 (2d Cir.), cert. denied, 414 U.S. 1033 (1973).

107. 342 U.S. 165 (1952).

108. 475 U.S. $312,319-20$ (1986).

109. 471 U.S. $1,8-11$ (1985). 